\title{
Determinants of foreign direct investment in real estate in European countries - panel data analysis
}

\author{
Sviatlana Anop \\ (Research engineer, Royal Instritute of Technology (KTH), Stockholm, Sweden) \\ Fastigheter och Byggande \\ Drottning Kristinas väg 30 \\ 10044 Stockholm Sweden \\ Tel.: +46879073 64; Fax: + 4697907367 \\ Email: sviatlana.anop@abe.kth.se
}

Foreign direct investments (FDI) have been one of the core features of globalization and the world economy over the past two decades. Statistical data shows that the level of FDI was continuously increasing during 2003-2007, but the directions and amount of such inflows differs significantly between the countries. Investments in real estate are just one of these inflows and European countries proved to be successful in this process. The objective of this study is to highlight theoretical and empirical findings about determinants of foreign direct investment in real estate in developed European countries. This paper first present and analyze existing scientific theories in this area with special attention to real estate investments, then focuses on assessing the relative significance of the factors that may attract FDI in real estate via a panel data regression analysis for a representative sample consisting of 15 OECD countries for 1996-2007. Results of the study suggest that certain variables such as size of GDP, human capital and road infrastructure appear to be robust under different specifications. Significance of these factors estimates are also observed, confirming the relevant theoretical propositions. However, certain differential variables that expected to have positive effect proved to be insignificant within the estimated data sample.

Keywords: Foreign Direct Investment, Real Estate, Panel Data Analysis

\section{Introduction}

Foreign direct investments (FDI) have been one of the core features of globalization and the world economy over the past two decades. Statistical data shows that the level of FDI inflows and outflows was continuously increasing during 2003-2007 (Figure 1). Investments in real estate are just one of these inflows. European countries proved to be successful in attracting FDI. According to UNCTAD (2007), in 2005 total FDI inflow in the world was 945,8 billion USD, of which developed countries received 590,3 billion USD which is 62,4 percent of the total FDI inflow in the world, whereas in the same year developing countries received FDI only 314,3 billion USD. It was only 38,6 percent of the total FDI inflow in the world. Even that one can observe a slight drop in total amount of FDI inflows in the world in 2008 (Table 1) developed countries continuously dominate over the developing countries in attracting the FDI.

The objective of this study is to highlight theoretical and empirical findings about determinants of foreign direct investment in real estate in developed European countries. The analysis is done via a panel data regression analysis for a representative sample consisting of 15 OECD countries for 1996-2007.

In the beginning this paper present and analyze existing scientific theories in this area with special attention to real estate investments. The conceptual framework is outlined in the third section. Econometric model and description of variables are presented in the fourth and fifth 
section. Next two sections are dedicated to econometric and sensitivity analysis, where regression is done and results of the model are discussed. Section eight concludes the paper.

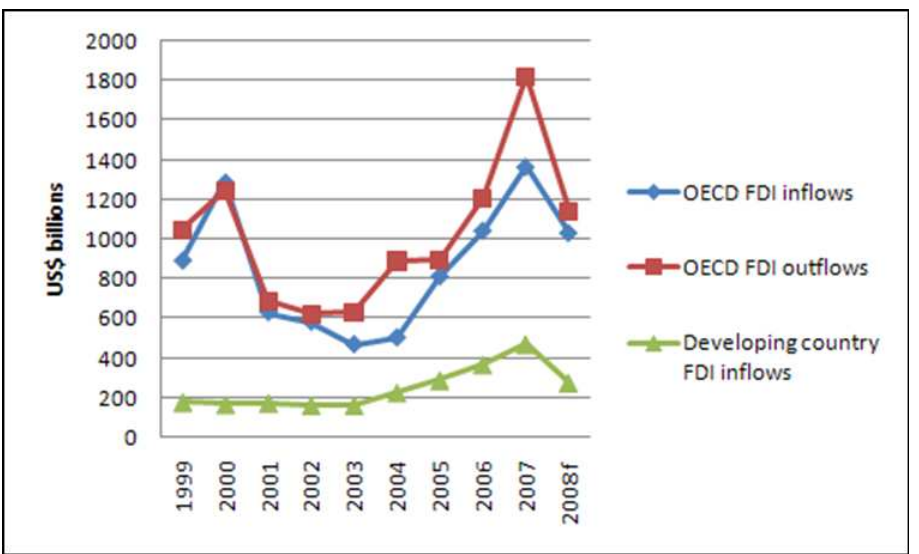

Source: OECD and estimates calculated by OECD Secretariat using 2008 data supplied by Dealogic. Developing country flow data through 2007 from World Bank (2008) Global Development Finance. OECD Investment news, June 2008, Issue 7. Retrieved 2010-04-30 from http://www.oecd.org/dataoecd/18/28/40887916.pdf

Figure 1. FDI Inflows and outflows, 1999-2007, and 2008 forecast

\begin{tabular}{|c|c|c|c|c|c|c|}
\hline \multicolumn{7}{|l|}{ FDI flows } \\
\hline & 2006 & $\%$ & 2007 & $\%$ & 2008 & $\%$ \\
\hline World & 1461074 & 100 & 1978838 & 100 & 1697353 & 100 \\
\hline $\begin{array}{l}\text { Developed } \\
\text { economies }\end{array}$ & 972762 & 66,6 & 1358628 & 68,7 & 962259 & 56,7 \\
\hline Europe & 631724 & 43,2 & 899627 & 45,5 & 518339 & 30,5 \\
\hline $\begin{array}{l}\text { European } \\
\text { union }\end{array}$ & 590305 & 40,4 & 842311 & 42,6 & 503453 & 29,7 \\
\hline $\begin{array}{l}\text { Developing } \\
\text { economies }\end{array}$ & 433764 & 29,7 & 529344 & 26,8 & 620733 & 36,6 \\
\hline \multicolumn{7}{|l|}{ FDI stocks } \\
\hline & 1990 & $\%$ & 2000 & $\%$ & 2008 & $\%$ \\
\hline World & 1942207 & 100 & 5757360 & 100 & 14909289 & 100 \\
\hline $\begin{array}{l}\text { Developed } \\
\text { economies }\end{array}$ & 1412605 & 72,7 & 3960321 & 68,8 & 10212893 & 68,5 \\
\hline Europe & 808943 & 41,7 & 2281563 & 39,6 & 6932525 & 46,5 \\
\hline $\begin{array}{l}\text { European } \\
\text { Union }\end{array}$ & 761897 & 39,2 & 2163354 & 37,6 & 6431893 & 43,1 \\
\hline $\begin{array}{l}\text { Developing } \\
\text { economies }\end{array}$ & 529593 & 27,2 & 1736167 & 30,1 & 4275982 & 28,7 \\
\hline
\end{tabular}

Source: UNCTAD. World investment report, 2009, pp. 247-251

Table 1. FDI flows and stocks inflows (Millions of dollars)

\section{Literature review}

Scientists determine several factors that can affect FDI, such as economic distance, transport/costs, market size, fiscal incentives, business and investment climate and political 
and economic risks, the size of the market, the rate of GNP growth, economic stability, the degree of openness of the economy, as well as several other institutional variables. A number of works (Swedenborg (1979), Dunning (1980) and Papanastassiou and Pearce (1990) are related to market-size hypothesis. It implies that international investments are "attracted by both the size of the host country and by the purchasing power of its inhabitants." "Sader (1993) in his cross-country regression, using data on 21 developing economies over the period 19881992, observed a strong correlation between FDI and market size. Billington (1999) has arrived to the conclusion that a larger market size is associated with a higher level of inward FDI. Holland and others (2000) reviewed a number of studies for Eastern and Central Europe and produced evidence of the importance of market size and growth potential as determinants of FDI.

Scientists determine also a number of other factors that affect FDI. Bevan and Estrin (2000) attempted to estimate determinants of Foreign Direct Investment in transition economies and found that FDI inflows are significantly influenced by risk, unit labour costs, host market size and gravity factors. Nunnenkamp and Spatz (2002), studying a sample of 28 developing countries during the 1987-2000 period, have found significant correlations between FDI flows and per capita GNP, risk factors, years of schooling, foreign trade restrictions, complementary production factors, administrative bottlenecks and cost factors. Population, GNP growth, firm entry restrictions, post-entry restrictions and technology regulation proved to be not significant. Nonnemberg and Cardoso de Medonco (2004) have made attempt to estimate the main determinants of FDI in developing countries. They have shown that such factors as the size and rate of growth of the product, the availability of skilled labor, the receptivity of foreign capital, the country risk rating, and the behavior of the stock market play important roles in FDI. Mottaleb (2007) using panel data from 60 developing countries to established that size and growth rate of GDP, business environment, as well as, modern communication facilities significantly affect the inflow of FDI, and FDI positively and significantly affects the GDP growth of a country.

As it is clearly seen from above FDI can be affected by different factors and their influence can change over time. However one can notice that there is a lack of research done for the developed countries, even that according to the statistics the bulk of FDI in the world happens to them. The previous study was done by Agiomirgianakis, Asteriou and Papathoma (2006), who have assessed the relative significance of the factors that may attract FDI via a panel data regression analysis for a sample consisting of 20 OECD countries for 23 years (1975-1997).

However, almost no research was done regarding investments in particular industries and assets, and more specifically regarding FDI in real estate. Moshirian F., Pham T. (2000) in their study of US FDI show that US financial wealth, US FDI in manufacturing and banking, US bilateral trade, foreign current account balance and US foreign financial liabilities contribute positively to the expansion of US FDI in real estate. Furthermore, by confirmed empirical results they show that as returns from the US stock market decline, there are more incentives for US investors to invest in foreign real estate.

In this study the determinants of FDI in real estate in 15 OECD Countries of European area will be estimated by using latest available data. All countries for which the data for FDI in RE was available were included in observation sample. However, only certain factors will be considered in the framework of this study due to the limited data available in OECD database.

\footnotetext{
${ }^{1}$ Bénassy-Quéré A., Coupet M., Mayer T. (2005). Institutional Determinants of Foreign Direct Investment, p.10
} 


\section{Conceptual framework}

The model is constructed by using the main findings in the previous academic studies. Many researches show that in terms of market oriented FDI, the most important factor to attract FDI is the size and growth of the host country. ${ }^{2}$ The market-size hypothesis suggests that a large market is necessary for the efficient utilization of resources and exploitation of economies of scale: as the market size grows to some critical value, FDI will start to increase thereafter (Scapelanda and Mauer, 1969). It is evident that "host countries with larger market size, faster economic growth and higher degree of economic development will provide more and better opportunities for these industries to exploit their ownership advantages and, therefore, will attract more market-oriented FDI." ${ }^{, 3}$ The intuition is that this factor can be significant for FDI in real estate sector.

The level of human capital is important determinant of the marginal productivity of capital. Different researches shows that skill-related variables are host-country specific. "When a host country is more appealing to labor-intensive foreign investment that requires a relatively low level of skills, the importance of the human capital variable tends to be small. On the other hand, labor skills can be a more significant factor for a host country, in which more capital and technology intensive investment projects are concentrated." In another research Lastly, Buckley and others (2002) used panel data for several regions in China for the 1989-98 period. They had not found any evidence support the hypothesis according to which the efficiency of FDI depends on a minimum level of human capital. Contrastingly, human capital is more significant in less developed provinces, while FDI stimulates growth notably in the more developed provinces.

Root and Ahmed (1979) has made a first attempt to establish the role of the general infrastructure level on FDI. Schneider and Frey (1985) estimated impact of infrastructure for less developing countries. Loree and Guisinger (1995) also constructed an indicator for infrastructure that encompassed measures such as highways, ports, communications and airports using principal components factor analysis and showed that the level of infrastructure did influence the flow of US direct investment. Kinoshita (1998) by using FDI data for seven Asian countries reported that infrastructure encourage firms to invest in a certain country. Kumar (2001) after analysis of composite index of infrastructure availability in 66 countries concluded that infrastructure development should become an integral part of the strategy to attract FDI inflows in general. That is why the variable of transport infrastructure will be also examined in this study.

Considering researches that have been done in this area before and the available data the dependence of FDI in RE on such variables as the real GDP growth, GDP size, human capital and road infrastructure will be estimated. Econometric model using these variables is presented in the next section.

\footnotetext{
${ }^{2}$ Main determinants and impacts of foreign direct investments on China's economy. OECD Working papers on international investments, November, 2000/4. p.11

${ }^{3}$ Main determinants and impacts of foreign direct investments on China's economy. OECD Working papers on international investments, November, 2000/4. p.11

${ }^{4}$ Chantasasawat B., K.C. Fung, lizaka H., Siu S. (2004). Foreign Direct Investment in East Asia and Latin America: Is there a People's Republic of China Effect? ADB Institute Discussion Paper No.17, p.12
} 


\section{Econometric models}

The assessment of the determinants of FDI In RE in OECD countries of European area by using panel data methodology. The main objective of this section is to outline the model used to empricially test the level of influence the explanatory variables have on FDI in RE. The panel data methodology combines information on the variation of the European countries with information taking place over time. One advantage of this methodology is that it allows heterogeneity among countries to be considered. The annual panel data consists of 15 OECD countries of European area and runs from 1996-2007 both are inclusive. A list of the countries and the sources of data are presented in the Appendix and the references.

The next step is to formally develop the panel data methodology in order to address the direct investment issue. Since both cross-section and time-series data are available, in general a panel data regression appears as follows:

$\mathrm{y}_{\mathrm{it}}=\mathrm{ai}_{\mathrm{i}}+\beta \mathrm{x}_{\mathrm{it}}+\varepsilon_{\mathrm{it}}(1)$

where the pair of terms (i, t) expresses the transversal and temporal aspects of the per country panel data, $y$ and $x$ are respectively the dependent variable and the matrix of explanatory variables, and $a_{i}$ (unobserved country heterogeneity) captures all unobserved, time constant factors that affect the dependent variable and $\varepsilon_{\text {it }}$ is an idiosyncractic error term that represents unobserved factors that change over time and $\varepsilon_{\text {it }}$ follows $\varepsilon_{\mathrm{it}} \sim\left(0, \sigma_{\mathrm{e}}{ }^{2}\right)$, while ai follows ai $\sim\left(0, \sigma_{\mathrm{a}}{ }^{2}\right)$. The set of independent variables is measured prior to the investment decision. In order to assess the influence of the variables described, a foreign investment equation may be built up in the following linear form:

FDIREi,t $=$ ai $+\beta 1$ GY i,t-1 $+\beta 2$ yi,t- $1+\beta 5$ h i,t- $1+\beta 6$ road i,t- $1+\varepsilon i t(2)$

where FDIRE - FDI in real estate,

GY - real GDP growth,

y - GDP,

$\mathrm{h}$ - human capital,

road - road infrastructure.

The equation (2) will be estimated by first-differencing(FD) over time and first-difference estimators will be obtained and as well as by fixed effect(FE) model in order to obtain the fixed effect estimators. For cross-sectional observation i, when the regression equation for year $t$ is subtracted from the regression equation for year $t+1$ (each variable is differenced over time),

FDIREi $, \mathrm{t}+1=\mathrm{ai}+\beta 1 \mathrm{GY} i, \mathrm{t}+\beta 2 \mathrm{yi}, \mathrm{t}+\beta 3 \mathrm{~h} \mathrm{i}, \mathrm{t}+\beta 4$ road $\mathrm{i}, \mathrm{t}+\varepsilon \mathrm{it}+1(3)$

FDIRE i,t $=a i+\beta 1$ GY i,t-1 $+\beta 2$ yi,t- $1+\beta 3$ h i,t- $1+\beta 4$ road i,t- $1+\varepsilon i t$ (4)

First-difference equation is set as follows:

$\Delta(\text { FDIRE })_{i, t}=\beta 1 \Delta \mathrm{GY}_{\mathrm{i}, \mathrm{t}}+\beta 2 \Delta \mathrm{y}_{\mathrm{i}, \mathrm{t}}+\beta 3 \Delta \mathrm{h}_{\mathrm{i}, \mathrm{t}}+\beta 4 \Delta \operatorname{road}_{\mathrm{i}, \mathrm{t}}+\Delta \varepsilon_{\mathrm{it}}(5)$

When time-demeaned transformation (fixed effects estimation) is applied to equation 1 , the general time demeaned equation for each country $i$ is:

$\mathrm{yi}, \mathrm{t}=\beta \mathrm{xi}, \mathrm{t}+\varepsilon \mathrm{it}$

where yi,t=(yi,t- $\left.\mathrm{T}^{-1} \sum_{\mathrm{t}=1}^{\mathrm{T}} \mathrm{yi}, \mathrm{t}\right)$,

$\mathrm{xi}, \mathrm{t}=\left(\mathrm{xi}, \mathrm{t}-\mathrm{T}^{-1} \sum_{\mathrm{t}=1}^{\mathrm{T}} \mathrm{xi}, \mathrm{t}\right)$,

$\varepsilon i t=\left(\varepsilon i, t-T^{-1} \sum_{t=1}^{T} \varepsilon i, t\right)$

and is unbiased within estimators will be produced under the strict exogeneity assumption on explanatory variables. Both methods explained above are used for estimating unobserved effect models by eliminating the unobserved effect from the equation with different transformations. The choice between FE and FD should be done according to the relative efficiency of estimators and this is determined by serial correlation in the idiosyncractic error 
term. Serial correlation will be tested by Wooldridge test for autocorrelation whose null hypothesis is that there is no first order correlation in $\varepsilon_{\text {it }}$. When $\varepsilon_{\text {it }}$ are serially uncorrelated, fixed effects model is more efficient than the first differencing. ${ }^{5}$

\section{The data}

The main sources of the data for analysis were statistical databases from OECD website. More detailed information about the data, criteria of sample choice and list of the selected countries is presented in the Appendix. The main variables that were used for this study are: FDI in RE is measured in millions US Dollars.

The Gross Domestic Product (GDP) measured in billion US Dollars is the way of measuring the size of country's economy.

Real GDP growth is measured in percentage.

Human capital is measured as a tertiary rate of the country. This is a percentage of population age 24-65 that enrolled in the tertiary schools.

Road reflects road infrastructure in the country and is measured as road fatalities per million inhabitants.

\begin{tabular}{|c|c|c|c|c|}
\hline Variable & & Mean & St.deviation & Observations \\
\hline FDI in RE & $\begin{array}{l}\text { overall } \\
\text { between } \\
\text { within }\end{array}$ & 581.7441 & $\begin{array}{l}1150.948 \\
631.6752 \\
939.7749\end{array}$ & $\begin{array}{cr}\mathrm{N}= & 152 \\
\mathrm{n}= & 15 \\
\mathrm{~T} \text {-bar }=10.1333\end{array}$ \\
\hline $\begin{array}{l}\text { Real GDP } \\
\text { growth }\end{array}$ & $\begin{array}{l}\text { overall } \\
\text { between } \\
\text { within }\end{array}$ & 3.203606 & $\begin{array}{l}1.619906 \\
.8831472 \\
1.379072 \\
\end{array}$ & $\begin{array}{cr}\mathrm{N}= & 179 \\
\mathrm{n}= & 15 \\
\mathrm{~T}-\mathrm{bar}= & 11.9333\end{array}$ \\
\hline GDP & $\begin{array}{l}\text { overall } \\
\text { between } \\
\text { within }\end{array}$ & 577.2047 & $\begin{array}{l}665.2582 \\
671.8814 \\
137.4232 \\
\end{array}$ & $\begin{array}{rr}\mathrm{N}= & 180 \\
\mathrm{n}= & 15 \\
\mathrm{~T}= & 12\end{array}$ \\
\hline Human capital & $\begin{array}{l}\text { overall } \\
\text { between } \\
\text { within }\end{array}$ & 21.96808 & $\begin{array}{l}7.551647 \\
7.416081 \\
2.278317\end{array}$ & $\begin{array}{cr}\mathrm{N}= & 148 \\
\mathrm{n}= & 15 \\
\mathrm{~T} \text {-bar }= & 9.86667\end{array}$ \\
\hline $\begin{array}{l}\text { Road } \\
\text { infrastructure }\end{array}$ & $\begin{array}{l}\text { overall } \\
\text { between } \\
\text { within }\end{array}$ & 106.9778 & $\begin{array}{r}39.64309 \\
37.8827 \\
14.98888 \\
\end{array}$ & $\begin{array}{rr}\mathrm{N}= & 180 \\
\mathrm{n}= & 15 \\
\mathrm{~T}= & 12\end{array}$ \\
\hline
\end{tabular}

Table 2. Descriptive statistics of the variables

\section{Results}

Equation (2) is considered by using 2 different methods to estimate unobserved model, first differencing and time-demeaned transformation (within estimator). The panel data set consists of 15 countries, and runs for a time span of 11 years (one year is missed due to the lags introduced in the equation). The estimated results are summarized in Table 3.

\footnotetext{
${ }^{5}$ Wooldridge J.M. (2009) Introductory Econometrics: A modern approach. Fourth edition, SouthWestern, Cengage learning. P.487
} 


\begin{tabular}{|c|c|c|c|}
\hline Dependent variable & \multicolumn{3}{|l|}{ FDIRE } \\
\hline Sample & \multicolumn{3}{|c|}{ Time period 1996-2007 $(\mathrm{T}=11)$, Number of countries $\mathrm{N}=15$} \\
\hline $\begin{array}{l}\text { Independent } \\
\text { variables }\end{array}$ & $\begin{array}{l}\text { First difference } \\
\text { model } *\end{array}$ & \begin{tabular}{|l|} 
Independent \\
variables
\end{tabular} & Fixed effect model \\
\hline $\begin{array}{l}\Delta \text { Gy }_{\mathrm{i}, t-1} \\
\text { (t-stat) }\end{array}$ & $\begin{array}{c}-156.435 \\
(1,49)\end{array}$ & $\begin{array}{l}\text { Gyi,t-1 } \\
\text { (t-stat) }\end{array}$ & $\begin{array}{c}104.7135 \\
(1,47)\end{array}$ \\
\hline $\begin{array}{l}\Delta \Delta \mathrm{y}_{\mathrm{i}, \mathrm{t}-1} \\
\text { (t-stat) }\end{array}$ & $\begin{array}{c}1.594518 \\
(1,02)\end{array}$ & \begin{tabular}{|l|}
$y_{i, t-1}$ \\
(t-stat)
\end{tabular} & $\begin{array}{c}2.332434 \\
(2,38)^{* *}\end{array}$ \\
\hline $\begin{array}{l}\Delta \mathrm{h}_{\mathrm{i},-1} \\
\text { (t-stat) }\end{array}$ & $\begin{array}{c}-31,31869 \\
(-0,35)\end{array}$ & $\begin{array}{l}\mathrm{h}_{\mathrm{i}, \mathrm{t}-1} \\
\text { (t-stat) }\end{array}$ & $\begin{array}{l}-149.926 \\
(-2,56)^{* *}\end{array}$ \\
\hline $\begin{array}{l}\Delta \text { roadi,t-1 } \\
\text { (t-stat) }\end{array}$ & $\begin{array}{c}-20,42877 \\
(-1,46)\end{array}$ & \begin{tabular}{|l} 
roadi,t-1 \\
(t-stat)
\end{tabular} & $\begin{array}{l}-28.38157 \\
(-2,78)^{* *}\end{array}$ \\
\hline $\begin{array}{r}\text { R-squared (overall) } \\
\text { (within) } \\
\text { (between) }\end{array}$ & $\begin{array}{l}0,0431 \\
0,0444 \\
0,0142\end{array}$ & $\begin{array}{r}\text { R-squared (overall) } \\
\text { (within) } \\
\text { (between) }\end{array}$ & $\begin{array}{l}0.1132 \\
0,1957 \\
0,1270\end{array}$ \\
\hline
\end{tabular}

Table 3. Estimation results

When the estimators of first-difference model are considered, the coefficients indicate trade off between explanatory variables and FDI in real estate. These estimated coefficients are not statistically significant at $95 \%$ level of statistical significance level. Both methods FE and FD are used for estimating unobserved effect models and choice between FD and FE is made after performing Wooldridge autocorrelation test for testing serial correlation in the idiosyncratic errors. By Wooldridge autocorrelation test autocorrelation in sit is not detected. Therefore, it is more efficient to estimate unobserved effect model with time-demeaned transformation on data of OECD countries of European area.

The column FE represents within estimators under the assumption that there is no differences between countries. An important finding is the positive and significant effect of GDP as expected before. FE estimation results suggest that road infrastructure and human capital are significant on the determination of FDI in RE, while GDP growth is insignificant. Results reveal that foreign investors are influenced by signal transmitted by GDP indicator. Human capital is negatively associated with FDI inflows, suggesting that all things being equal, investors are less likely to invest in the countries which have achieved a certain level of development. This result is unexpected, but seems to be reasonable for developed countries in contrast to developing countries, where this variable seems to play an opposite role according to recent studies. Road infrastructure estimate that is measured as a road fatalities per million inhabitants negatively affects investments in real estate, that is consistent with the expected result.

\section{Sensitivity analysis}

As it has been found in the previous section, the significant explanatory variables that have effect on determination of FDI in RE inflows were GDP, human capital and road infrastructure of the host country. The sensitivity analysis is done in order to check how sensitive results to changes in model. The insignificant variable GDP growth is taken away from the model. The FE estimators are presented in table 4. 


\begin{tabular}{|l|l|}
\hline Dependent variable & FDIRE \\
\hline Sample & \multicolumn{2}{|l|}{ Time period 1996-2007 (T=11), Number of countries N=15 } \\
\hline Independent variables & Fixed effect model \\
\hline yi,t-1 & 2.090772 \\
& $(2,16)^{* *}$ \\
\hline hi,t-1 & -150.2921 \\
& $(-2,55)^{* *}$ \\
\hline roadi,t-1 & -29.29578 \\
& $(-2,86)^{* *}$ \\
\hline R-squared (overall) & 0.0920 \\
\hline ** statistically significant at \%95 level of significance \\
\hline
\end{tabular}

Table 4: Summary of FE estimators for sensitivity analysis

For GDP, human capital and road infrastructure almost the same result is obtained as before, so the changes in the model do not affect the statistical significance of these variables.

\section{Conclusion}

FDI inflows could bring important benefits to the recipient economies in the form of capital inflows, technology transfer, human capital formation, international trade integration and enterprise development. That is why it is important to know what factors affect the FDI inflow to the country and especially investments in real estate. The objective of this study was to highlight the determinants of foreign direct investment in real estate in developed countries since they have shown a great success in attracting FDI. An econometric model based in panel data analysis for 15 OECD countries of European area for the 1996-2007. The variables selected to explain direct foreign investment in real estate were the real GDP growth, size of GDP, the level of human capital and development of road infrastructure.

It was found that estimates of GDP (as a measure of market size) have positive effect and are significant for the selected sample. The degree of the human capital and road infrastructure were included as a proxy to reflect the willingness of a country to accept foreign investment in real estate. These variables proved to be important in attracting foreign capital.

Estimate of GDP growth (as a measure of market size growth) was not significant for the selected sample. This can be explained by the fact that GDP growth historically does not differ greatly between European countries as for example between developing countries, where according to the recent studies this variable positively affect FDI inflows.

\section{References}

Agiomirgianakis G., Asteriou D. and Papathoma K., (2006). The determinants of foreign direct investment: a panel data study for the OECD countries. City University London, Discussion Paper Series, No. 03/06, pp.1-19. Retrieved 2010-02-12 from http://zunia.org/uploads/media/knowledge/0306.pdf

Bevan A., Estrin S., 2000. The Determinants of Foreign Direct Investment in Transition Economies. William Davidson Institute, Working Paper Number 342, October 2000, pp.1-57. Retrieved 2010-02-12 from http://www.wdi.umich.edu/files/Publications/WorkingPapers/wp342.pdf

Bénassy-Quéré A., Coupet M., Mayer T. (2005). Institutional Determinants of Foreign Direct Investment, pp.1-30. Retrieved 2010-02-01 from 
http://www3.interscience.wiley.com/journal/117965550/abstract?CRETRY=1\&SRETRY=0

Billington, N. (1999). The Location of Foreign Direct Investment: An Empirical Analysis, Applied Economics, 31, pp. 65-76.

Chantasasawat B., K.C. Fung, Iizaka H., Siu S. (2004). Foreign Direct Investment in East Asia and Latin America: Is there a People's Republic of China Effect? ADB Institute Discussion Paper No.17, pp.1-32. Retrieved 2010-02-16 from

http://papers.ssrn.com/sol3/papers.cfm?abstract_id=711224

Chakrabarti A. (2001). The Determinants of Foreign Direct Investment: Sensitivity Analyses of Cross-Country Regressions. Kyklos, Vol. 54. pp. 89-114. Retrieved 2010-02-20 from http://ideas.repec.org/a/bla/kyklos/v54y2001i1p89-113.html

Dailami M.(2008) Mobilizing international resources for development: Foreign Direct

Investments and other Direct flows. Presentation, New-York. Retrieved 2010-02-24 from www.un.org/esa/ffd/doha/chapter2/Dailami_WorldBank.ppt

Drukker D.M(2003) Testing for serial correlation in linear panel-data models. Stata Journal,3, Number2,p171

Dunning, J.H. (1980) The Location of Foreign Direct Investment Activity, Country

Characteristics and Experience Effects, Journal of International Business Studies, pp.9-22

Edwards, S. (1990). Capital Flows, Foreign Direct Investment, and Debt-Equity Swaps in

Developing Countries, National Bureau of Economic Research (Cambridge, M. A.), Working

Paper No. 3497. Retrieved 2010-02-20 from

http://www.emeraldinsight.com/Insight/ViewContentServlet?

Filename=/published/emeraldfulltextarticle/pdf/0090320703_ref.html

Holland D., Sass M., Benacek V., Gronicki M.(2000). The determinants and impact of FDI in central and eastern Europe: a comparison of survey and econometric evidence. Transnational Corporations, Vol 9 (3).

Kinoshita Y, Campos N,( 2004) Estimating the Determinants of Foreign Direct

Investment Inflows: How Important are Sampling and Omitted Variable Biases? CEPRWDI Transition Conference

Kumar, N (2001), Infrastructure Availability, Foreign Direct Investment Inflows and Their Export-orientation: A Cross-Country Exploration. Research and Information System for Developing Countries, New Delhi, November 2001

Loree D. W. and S. E. Guisinger (1995), Policy and non-policy determinants of U.S. equity foreign direct investment, Journal of International Business Studies, 26 (2), 281- 299.

Main determinants and impacts of foreign direct investments on China's economy. OECD Working papers on international investments, November, 2000/4.pp.1-38. Retrieved 2010-0212 from http://www.oecd.org/dataoecd/57/23/1922648.pdf

Moshirian F., Pham T. (2000) Determinants of US investment in real estate abroad. Journal of Multinational Fiancial Management. Volume 10, Issue 1, January 2000, pp.63-72

Mottaleb K.A. (2007). Determinants of Foreign Direct Investment and Its Impact on

Economic Growth in Developing Countries. Munich Personal RePEc Archive, December, 2007, pp.1-15. Retrieved 2010-02-12 from

http://mpra.ub.uni-muenchen.de/9457/1/MPRA_paper_9457.pdf

Nonnemberg M.B., Cardoso de Medonco M.J.(2004). The determinants of foreign direct investments in developing countries.pp.1-20. Retrieved 2010-02-12 from

http://www.anpec.org.br/encontro2004/artigos/A04A061.pdf

Nunnenkamp P, Spatz J. (2002) Determinants of FDI in developing countries: has globalization changed the rules of the game? Transnational Corporations, Vol 11 (2)

OECD Investment news, June 2008, Issue 7. Retrieved 2010-04-30 from http://www.oecd.org/dataoecd/18/28/40887916.pdf 
Pappanaatassiou, M. and R. D Pearce (1990). Host Country Characteristics and the Sourcing Behavior of the UK Manufacturing Industry, Discussion Paper, University of Reading.pp.922.

Root, F.R. and A.A. Ahmed (1979) Empirical Determinants of Manufacturing Direct Foreign Investment in Developing Countries, Economic Development and Structural Change, 27, 751-767.

Sader F. (1993). Privatization and Foreign Investment in the Developing World, World Bank Working Paper No. 1202. Retrieved 2010-02-20 from http://econ.worldbank.org/external/default/main? page $\mathrm{PK}=64165259 \&$ the $S i t e \mathrm{PK}=469372 \& \mathrm{piPK}=64165421 \&$ menuPK $=64166093 \&$ entity $\mathrm{ID}=0$ 00009265_3961005100739

Scaperlanda, A. E. and Mauer L.S. (1969). The Determinants of U.S. Direct Investment in the E.E.C., American Economic Review, 59, pp. 558-568.

Schmitz, A. and J. Bieri (1972). EEC Tariffs and U S. Direct Investment, European Economic Review. 3:259-270.

Singh, H. and Jun, K.W. (1995). Some New Evidence on Determinants of Foreign Direct Investment in Developing Countries. Policy Research Working Paper No.1531, The World Bank. Retrieved 2009-11-22 from http://ideas.repec.org/p/wbk/wbrwps/1531.html

Schneider, F. and Frey, B. (1985), Economic and Political Determinants of Foreign Direct Investment, World Development, 13(2), 161-175.

Solow, R.M.(1956), "A contribution to the Theory of Economic Growth", Quarterly Journal of Economics, 65-94

Swedenborg, B. (1979). The Multinational Operations of Swedish Firms: Analysis of

Determinants and Effects, Working Paper, Industrial Institute of Economic and Social Research, Stockholm.

UNCTAD (2007). World Investment Report 2007: Transnational Corporations.

Extractive Industries and Development. New York: United Nations. Retrieved 2010-02-01

from http://www.unctad.org/en/docs/wir2007_en.pdf

UNCTAD (2009). World investment report, 2009. Transnational Corporations,

Agricultural production and Development. New York and Geneva: United Nations. Retrieved 2010-02-16 from http://www.unctad.org/en/docs/wir2009_en.pdf

Wooldridge J.M. (2009) Introductory Econometrics: A modern approach. Fourth edition, South-Western, Cengage learning.

\section{Electronic resource links:}

Data source for FDI in real estate, GDP, Real GDP growth, Tertiary rates, Road infrastructure: http://stats.oecd.org/index.aspx

\section{Appendix}

List of selected countries:

1. Austria

9. Netherlands

2. Czech republic 10. Norway

3. Denmark 11. Poland

4. Finland

12. Slovak republic

5. France

13. Spain

6. Germany

14. Sweden

7. Greece

15. United Kingdom

8. Hungary 